land was but small in proportion, and after swaying about for a few yards, died away.

I have been informed of similar cases in this district, but the above is the only instance in which I observed a waterspout myself.

H.M. Geological Survey, Wisbech, May 2.

\section{The Geologists' Association at Watford}

IN the notice in your last number of the excursion of the Geologists' Association to Watford there is a slight error which perhaps I may be permitted to correct.

The sections of the Woolwich and Reading Series which were examined are at Watford Heath Kiln and at Bushey Kiln (not Bushey Heath), and the formation, although varying very much in the short distance (scarcely a mile) that these places are apart, is at each place represented by beds of clay, sand, and pebbles. The pebble beds are, however, better seen at the latter than at the former place. JOHN HOPKINSON

Temperature of Hill and Valley

IN NATURE of May 2, page I9, there is an interesting report of a paper by Mr. Lines " On the Temperature of Hill and Valley," showing that (to use Mr. Gaster's words in the discussion) "the air is colder on the top of the hill than in the valley, by day, when the sun is shining, and warmer at night when it is not shining." This appears anomalous at first sight, but I believe it has long been known, and it is easily exp'ained. The temperature of the hill top is not produced where it is observed. As Mr. Glaisher stated in the same discussion, the higher we go in a ba'loon the less is the range of temperature; and the tem. perature at the top of a hill which is at all isolated, or even steep on one side, approximates to that observed in a balloon at the same absolute height.

The reason why temperature has a less range in the higher atmospheric strata, is that the earth has very much more power of both absorbing and radiating heat than the molecules of alr, and consequently heats more rapidly in the daytime and cools more rapidly at night. The temperature of air at the surface of the earth is determined much more by the absorption and radiation of the earth than by its own.

The truth of this view is shown by the fact that the law is quite different for table-lands from that which we have seen to be true for isolated hills. On table-lands the diurnal range of temperature is greater than on low plains, though on isclated hills it is less. These facts appear to show that while, other conditions being given, the mean temperature of a station chiefly depends on its height above the sea level (or, in other words, the thickness of the atmosphere above it) the diurnal range at the station (whether hill top or balloon) chiefly depends on the proximity of ${ }_{i}$ the atmospheric stratum surrounding it to the surface of the earth.

The fact stated in the same paper that " in cold weather the air on the top of the hill is never so cold as that in the valley," is no doubt partly due to the cause above stated, but partly also, I think, to the fact that cold air is heavier than warm, and seeks the lowest position. I believe there is no doubt this is the explanation of the glacières or freezing caverns of the Jura described in the Rev. Harold Browne's book.

Old Forge, Dunmurry, Co. Antrim, May 8

JOSEPH JOHN MURPHY

\section{Meteors}

I OBSERVED a meteor at about half-past eleven on the night of the 8th inst., in the constellation Scorpio, which passed very close to the star Antares, travelling from right to left.

It appears to me worth remarking from the fact of its course lying very near, and roughly parallel to, that part of the ecliptic which corresponded to the earth's position in her orbit.

It traversed some eight or ten degrees of arc, and was visible for three or four seconds, gradually increasing in brightness till it was nearly on a par with Antares, which star it also resembled in colour. Its slow apparent motion immediately suggested the idea that it was moving in the same plane and direction as the earth; in fact, that it was overtaking us in an orbit just outside our own.

The course of another meteor, seen about half an hour earlier from a westerly window, and described to me as not very inferior to Jupiter, appears also to have lain in the direction of the ecliptic, but from left to right, in the neighbourhood of the constellations Gemini, Cancer, or Leo.

It is rash to generalise from such insufficient data, but I conceive these meteors may both have belonged to a system whose orbit lies nearly in the plane of the earth's ; the apparent retrograde notion of the last.named being caused by the direction of its path crossing our orbit at a point behind the earth's then place instead of in advance of $i t$.

Cardiff, May Io

Geo. C. Thompson

\section{The Ivory Crayñsh}

I THINK it may be interesting to some of the readers of NATURE to know that a specimen of the "Ivory crayfish," or Astacus (Cambarus) pellucidus, mentioned in the very interesting communication of Dr. Packard on the Mammoth Cave of Kentucky in NatURE, April r8, has been living in the aquarium.house in the Regent's Park for a considerable time. The specimen was brought over at the close of the last year by Mr. Boyd from the Mammoth Cave; it is now placed in the first fresh-water tank on the right hand of the visitor as he enters the aquarium. Its dark-loving habits do not permit it to be seen much, as it generally burrows partially under a large stone, from beneath which only the tips of its white claws can be seen.

Culverlea, Winchester, May 8

W. A. FORBES

\section{THE AMERICAN ACADEMY OF SCIENCES}

THE Annual Meeting of the National Academy of Sciences was convened, on the 16 th of April last, at the Smithsonian Institution in Washington. The existence of this body was authorised by an Act of Congress passed in 1863; and it was originally limited to fifty members, designed to represent the most eminent men of science in the country, who were to be organised for the purpose of serving as advisers to the United States Government in questions of a scientific nature. The Academy has rendered excellent service in this capacity, and has had referred to it very many important questions, the satisfactory solutions of which have saved much money to the Government, and increased the efficiency of many of its bureaus. One condition of membership is that all such service to the Government is to be performed without charge.

As this Society, by its national character, takes the lead of State Institutions for a similar object, and the number of members was at first limited, considerable dissatisfaction was felt by many persons who believed themselves worthy of membership, but were excluded by this restriction. The Academy, therefore, after mature deliberation, decided to ask Congress to remove the limitation as to number, which being done, the principal business of the Academy at its late meeting consisted in the increase of its force. Twenty-five new members were selected, representing the various branches of theoretical and applied science, and the number is to be increased by five each succeeding year. Very few papers or communications were presented to the Academy, as all the time of the meeting was required in carrying out the changes involved by the alteration of the charter, including the formation of a new constitution and rules for its government.

The following is the list of members elected:- Prof. C. A. Young, Dartmouth ; Prof. E. D. Cope, Philadelphia; Prof. J. Lawrence Smith, Louisville ; W. S. Sullivant, Columbus ; Prof. W. B. Rogers, Boston ; J. H. Trumbull Hartford; Prof. J. P. Cooke, Cambridge ; Dr. A. S Packard, jun., Salem; Prof. W. P. Trowbridge, New Haven; J. E. Oliver, Massachusetts; Prof. E. W. Hilgard, Oxford, Maine ; Prof. R. Pumpelly, State Geologist, Missouri ; Prof. J. H. Lane, Coast Survey ; Prof. A. E. Verrill, New Haven; Dr. J. W. Crafts; Theodore Lyman, Boston; Prof. A. M. Mayer, Stevens Institute, Hoboken Prof. H. J. Clarke, Amherst ; J. Ericsson; Prof. Hadley, New Haven; Dr. F. A. Genth, Philadelphia; Charles A. Schott, Coast Survey ; Prof. A. H. Worthen, State Geolo gist, Illinois ; Captain J. B. Eads, St. Louis ; General H. L. Abbott, U.S.A. 